\title{
Differences in Anthropometrics Characteristics and Body Composition Between Two Elite Youth Male Basketball National Teams-Participants at U18 European Championship 2019
} Diferencias en las Características Antropométricas y la Composición Corporal entre dos Equipos Nacio-
nales de Baloncesto Masculino Juvenil de Élite - Participantes en el Campeonato de Europa U18 2019

Milovan Ljubojevic ${ }^{1,2}$; Danilo Bojanic ${ }^{1}$; Dragan Krivokapic ${ }^{1}$; Aldijana Nokic ${ }^{1}$ \& Nina Dukanovic ${ }^{3}$

LJUBOJEVIC, M.; BOJANIC, D.; KRIVOKAPIC, D.; NOKIC, A. \& DUKANOVIC, N. Differences in anthropometrics characteristics and body composition between two elite youth male basketball national teams - participants at U18 European Championship 2019. Int. J. Morphol., 38(6):1528-1534, 2020.

SUMMARY: The aim of this research was to determine the differences among the male basketball players of the National team of Montenegro U18 and the National team of Republic of North Macedonia, in terms of their anthropometric characteristics and body composition. A sample of 27 subjects was divided into two sub-samples. The first sub-sample of the subjects consisted of 15 players of the National team of Montenegro, average age 17.6 \pm 0.63 , while the other sub-sample consisted of 12 players of the National team of Republic of North Macedonia, average age of 17.17 \pm 0.72 . All players were tested in Podgorica, in lasting period of two days, while they held preparations for the European Championship. Anthropometric characteristics and body composition were evaluated by a battery of eleven variables: body height $(\mathrm{cm})$, body weight $(\mathrm{kg})$, triceps skinfold, back skinfold, biceps skinfold, abdominal skinfold, thigh skinfold, calf skinfold, body mass index (BMI), percentage of fat and muscle mass (kg). Differences in anthropometric characteristic and composition of the body of the basketball players of two national teams were determined by using a discriminatory parametric procedure with t-test for small independent samples $(\mathrm{p}<0.05)$. The players of the two teams were found to differ statistically in thigh skinfold. Furthermore, it is concluded that Montenegro players are taller and heavier and have higher muscle mass than North Macedonian players, with approximate skinfolds, BMI and fat percentage values.

KEY WORDS: Anthropometric characteristics; Body composition; Young basketball players.

\section{INTRODUCTION}

The evolution of basketball, since its inception, in 1891 , and to this day, is characterized by major changes in the demands placed before the top players (Ljubojevic \& Nikolic, 2012). Although the basic rules are practically the same, the characteristics of the game itself, speed, pace, energy, length of attack, number of shots scored, points scored, number of sprints, rebounds, duels, fouls, are changing very fast and in some way are defined as more complicated. In such conditions, basketball places extremely high demands on athletes when it comes to the player's morphological characteristics and motor ability (Sisodiya \& Yadaf 2010; Ljubojevic \& Nikolic; Popovic et al., 2013), and also determines selection criteria for this sport.

Basketball is a team sport and as a game is a highly dynamic activity characterized by explosive movements. It represents a structurally complex sport that is composed of numerous movements. It requires players to possess excellent skills of high level, morphological characteristics and motor skills (Ljubojevic \& Nikolic; Popovic et al.; Ochoa et al., 2014). When it comes to anthropometry, we need to know that anthropometry is important, above all, in the selection of basketball players. On the other hand, their performance and skills, to a greater or lesser extent, are closely linked to anthropometric characteristics (Claessens et al., 1991; Carter et al., 2005). Basketball requires above average tall individuals, with large longitudinal body dimensions to cover as much space on the ground as possible (played both horizontally and vertically). In addition to longitudinal dimensions (body height, arm span, reach height, etc.), very important indicators for basketball are the volume and weight of the body, as well as the evaluation of subcutaneous adipose

\footnotetext{
${ }^{1}$ Faculty for Sport and Physical Education, University of Montenegro, Niksic, Montenegro.

${ }^{2}$ Basketball Federation of Montenegro.

${ }^{3}$ High medical school Milutin Milankovic - Belgrade, Serbia.
} 
LJUBOJEVIC, M.; BOJANIC, D.; KRIVOKAPIC, D.; NOKIC, A. \& DUKANOVIC, N. Differences in anthropometrics characteristics and body composition between two elite youth male basketball national teams - participants at U18 European Championship 2019. Int. J. Morphol., 38(6):1528-1534, 2020.

tissue (Riezebos et al., 1983; Shambaugh et al., 1991; Masanovic, 2019; Ljubojevic et al., 2020).

Basketball is the second most popular sport in Montenegro. Although a very small country, with a population of 622,359 (official data from January 2018), Montenegro is a regular participant in the European Seniors Championships (Lithuania 2011, Slovenia 2013, Finland, Israel, Romania, Turkey, 2017). In addition, it is the smallest country to ever participate in the World Basketball Championship, in China 2019. Also, the junior selections of Montenegro are regular participants of the European Championships Division A under 16, under 18, under 20, which is a great success considering the size of the country and the size of the sample from where selection is made.

It is a similar situation when it comes to basketball in the Republic of North Macedonia. The senior selection was most successful at EuroBasket 2011 in Lithuania, where it placed 4th. They also participated in France (1999), in Poland (2009), in Slovenia (2013) and in Croatia (2015).

Due to the above, the aim of this research was to show the values of the morphological characteristics of two national teams. Specifically, to compare variables of the best Montenegrin young basketball players with the variables of the young basketball players of the other European team such as the Republic of North Macedonia, which is also a European Championship participant, but in B Division. Finally, based on this outcome, compare potential specificities in the selected variables.

\section{MATERIAL AND METHOD}

Sample of subjects. A sample of the subject consists of total of 27 top-level male junior players who were members of two national teams that participated on U18 European Championship 2019, Division A and Division B. The first sub-sample of the subjects consisted of 15 players of National team of Montenegro, average age 17.6 \pm 0.63 , and 12 players of National team of Republic of North Macedonia, average age 17.17 \pm 0.72. The players were tested in June 2019 in Podgorica, when two teams held preparations for the European Championship.

Sample of measures. Anthropometric measurements were taken according to the IBP-International Biology Program recommendations. For the purpose of this study 8 morphological measures have been taken: body height, body weight, triceps skinfold, biceps skinfold, back skinfold, abdominal skinfold, calf skinfold, thigh skinfold, and 3 body composition assessment variables: body mass index (BMI), fat percentage and muscle mass. Tanita body fat scale model BC-418MA was used to evaluate the body composition. The principle of this scale is based on indirect measurement of the body composition; a safe electrical signal is transmitted through the body via electrodes located in the standalone unit. Tanita scale, thanks to its athletics mode, enables athletes to closely monitor their body weight, health condition and form with all relevant parameters. Anthropometer and caliper were used for morphological measurements.

Data processing method. The data obtained through the research are processed by descriptive and comparative statistical procedures. For each variable, central and dispersion parameters, as well as asymmetry and flattening measures are processed. Differences in anthropometric characteristics and the composition of the body of the basketball players of these two national teams, were determined by using a discriminatory parametric procedure with t-test for small independent samples, with statistical significance of $p<0.05$.

\section{RESULTS}

Basic descriptive statistical parameters of anthropometric variables and body composition of the basketball players of the two national teams, where the values of central measurements and dispersion tendencies are calculated, are presented in Tables I and II: minimal (Min) and maximal (Max) values, arithmetic mean (Mean), standard deviation (S.D.), coefficient of curvature (Skewness) and elongation (Kurtosis). First, the central and dispersion parameters of the variables were analyzed to evaluate the anthropometric characteristic and body composition of the basketball players of National team of Montenegro (Table I).

As shown in Table I, it can be noted that all the variables are placed within the normal distribution boundaries, which results are based on dispersion and central parameters. In general, according to all the statistical parameters listed, we can conclude that the survey is conducted on a sample that is known for top basketball players. By the value of skewness, it can be noticed that in the variables of the triceps skinfold (1.14), back skinfold (0.57), biceps skinfold (1.76), and abdominal skinfold $(1,54)$ show that most results of these skinfolds are among lower values. There was a slight inclination on the side of the lower results, which brings us to a positive conclusion because subcutaneous fat is a disrupting factor for professional athletes. Majority results of other variables are among higher values. An insight into 
LJUBOJEVIC, M.; BOJANIC, D.; KRIVOKAPIC, D.; NOKIC, A. \& DUKANOVIC, N. Differences in anthropometrics characteristics and body composition between two elite youth male basketball national teams - participants at U18 European Championship 2019. Int. J. Morphol., 38(6):1528-1534, 2020.

Table I. Descriptive data for Montenegro's U18 basketball players (N=15).

\begin{tabular}{lccccc}
\hline Variable & Min & Max & Mean \pm SD & Skewness & Kurtosis \\
\hline Age & 16 & 18 & $17.6 \pm 0.63$ & -1.407 & 1.264 \\
Body height $(\mathrm{cm})$ & 180.3 & 208.7 & $193.9 \pm 8.9$ & 0.113 & -1.24 \\
Body weight $(\mathrm{kg})$ & 76.7 & 97 & $87.01 \pm 6.72$ & -0.289 & -1.2 \\
Triceps skinfold & 4.6 & 12.4 & $7.15 \pm 2.31$ & 1.144 & 0.524 \\
Back skinfold & 7.2 & 15.6 & $10.89 \pm 2.39$ & 0.571 & -0.287 \\
Biceps skinfold & 3.3 & 7.2 & $4.49 \pm 1.05$ & 1.763 & 2.941 \\
Abdominal skinfold & 6.6 & 20.2 & $13.07 \pm 4.22$ & 0.332 & -0.833 \\
Calf skinfold & 3 & 10.6 & $6.36 \pm 2.1$ & 0.664 & 0.109 \\
Thigh skinfold & 4.6 & 12.6 & $9.04 \pm 2.19$ & -0.14 & -0.319 \\
Body mas Index BMI & 19.2 & 26.4 & $23.16 \pm 1.74$ & -0.448 & 0.981 \\
Percentage of fat (\%) & 2.4 & 14.8 & $10.49 \pm 3.6$ & -0.6 & 0.036 \\
Muscle mass (kg) & 37.2 & 48.6 & $44.09 \pm 3.59$ & -0.413 & -1.017 \\
\hline
\end{tabular}

the results of the peak of the Gaussian curve (kurtosis) shows that for most variables there is no significant deviation from the normal distribution of the results. The most significant deviation from the normal values is seen in the variables age (1.26), biceps skinfold (2.94), where results are majorly accumulated about the center of distribution, whilst the values are greater at the end of the curves when it comes to body height (-1.24), body weight (-1.2) and muscle mass (1.07), where athletes are most homogeneous.

Table II showed the central and dispersion parameters of the variables that were analyzed to evaluate the anthropometric characteristics and body composition of the basketball players of Republic of North Macedonia.

Based on the central and dispersion parameters of the values of the skewness and the kurtosis of the players of the Republic of North Macedonia it can be stated that all the variables are within the normal distribution boundaries and that the values are very similar to those of the basketball players from Montenegro. However, a comparative statistical procedure, t-test (Table III), will show whether this is statistically significant. By the value of the skewness, it can be noticed that in the variables of the triceps skinfold and biceps skinfold show that most results of these skinfolds are among lower values. Most results are normally distributed. The largest significant deviation from the normal values is seen in the variables triceps skinfold and BMI where there are more results accumulated around the distribution center, while kurtosis values (body height, calf skinfold, thigh skinfold and muscle mass) show that most results are about the final values of these variables.

In order to determine whether there are statistically significant differences in the analyzed variables of the top young basketball players of these two national teams, the statistical procedure t- test (Table III) was applied.

Based on results of t-test (Table III) it was found that basketball players of two national teams have statistically significant differences by the one variable that estimates the thigh skinfold.

Table II. Descriptive data for Republic of North Macedonia's U18 basketball players (N=12).

\begin{tabular}{lccrrc}
\hline Variable & Min & Max & \multicolumn{1}{c}{ Mean \pm SD } & Skewness & Kurtosis \\
\hline Age & 16.00 & 18.00 & $17.17 \pm 0.72$ & -0.262 & -0.685 \\
Body height $(\mathrm{cm})$ & 179.50 & 200.40 & $190.86 \pm 7.38$ & -0.23 & -1.359 \\
Body weight (kg) & 65.60 & 98.50 & $82.96 \pm 9.76$ & -0.415 & -0.453 \\
Triceps skinfold & 5.60 & 12.60 & $7.8 \pm 2.21$ & 1.512 & 1.47 \\
Back skinfld & 6.20 & 13.40 & $9.23 \pm 2.24$ & 0.606 & -0.34 \\
Bic eps skinfold & 3.00 & 8.80 & $4.99 \pm 1.68$ & 1.114 & 0.976 \\
Abdominal skinfold & 4.60 & 22.60 & $11.08 \pm 6.08$ & 1.047 & -0.33 \\
Calf skinfold & 4.60 & 8.60 & $6.76 \pm 1.47$ & -0.211 & -1.316 \\
Thigh skinfold & 8.40 & 13.40 & $10.77 \pm 1.71$ & 0.363 & -1.404 \\
Body mas Index BMI & 18.90 & 26.60 & $22.72 \pm 1.89$ & 0.032 & 1.588 \\
Percentage of fat (\%) & 2.70 & 20.30 & $11.05 \pm 5.44$ & 0.526 & -0.635 \\
Muscle mass (kg) & 34.50 & 48.20 & $41.68 \pm 4.92$ & -0.084 & -1.382 \\
\hline
\end{tabular}


LJUBOJEVIC, M.; BOJANIC, D.; KRIVOKAPIC, D.; NOKIC, A. \& DUKANOVIC, N. Differences in anthropometrics characteristics and body composition between two elite youth male basketball national teams - participants at U18 European Championship 2019. Int. J. Morphol., 38(6):1528-1534, 2020

Table III. Descriptive data and t-test for 27 male basketball players members of two national teams (Montenegro U18 and Republic of North Macedonia U18).

\begin{tabular}{lcccc}
\hline & MONTENEGRO & RN MACEDONIA & & \\
\hline Variables & Mean \pm SD & Mean \pm SD & t & Sig. \\
\hline Age & $17.6 \pm 0.63$ & $17.17 \pm 0.72$ & 1.643 & .115 \\
Body height $(\mathrm{cm})$ & $193.9 \pm 8.9$ & $190.86 \pm 7.38$ & .971 & .341 \\
Body weight $(\mathrm{kg})$ & $87.01 \pm 6.72$ & $82.96 \pm 9.76$ & 1.226 & .235 \\
Triceps skinfold & $7.15 \pm 2.31$ & $7.8 \pm 2.21$ & -.748 & .462 \\
Back skinfold & $10.89 \pm 2.39$ & $9.23 \pm 2.24$ & 1.869 & .075 \\
Biceps skinfold & $4.49 \pm 1.05$ & $4.99 \pm 1.68$ & -.896 & .382 \\
Abdominal skinfold & $13.07 \pm 4.22$ & $11.08 \pm 6.08$ & .964 & .347 \\
Calf skinfold & $6.36 \pm 2.1$ & $6.76 \pm 1.47$ & -.580 & .567 \\
Thigh skinfold & $9.04 \pm 2.19$ & $10.77 \pm 1.71$ & -2.303 & $.030^{*}$ \\
Body mass index(BMI) & $23.16 \pm 1.74$ & $22.72 \pm 1.89$ & .627 & .537 \\
Percentage of fat (\%) & $10.49 \pm 3.6$ & $11.05 \pm 5.44$ & -.309 & .761 \\
Muscle mass (kg) & $44.09 \pm 3.59$ & $41.68 \pm 4.92$ & 1.427 & .169 \\
\hline
\end{tabular}

* Sig $(\mathrm{p}<0.05)$

\section{DISCUSSION}

In the last couple of decades, basketball has undergone major changes. By changing the rules of the basketball game in terms of shortening attack time, changes in the dynamics and style of the game, it resulted that basketball became more demanding for players and implies anthropological characteristics adequate to that level of quality performance, as well as functional and motor skills. Morphological characteristics occupy an increasingly important place in the primary selection of basketball players (Ljubojevic et al.).

Having an insight at the results of body height, we can conclude that the players of Montenegro are higher than the players of North Macedonia, but not at the level of statistical significance. To see how different these two selections are from their peers in the other European teams, here we will also show the values of the body height selections of the FIBA U18 European Championship Division A, and Division B, from 2019, in order of the wining place in the championship.

According to an average height of players, shown in Table IV, we can conclude that out of the total of 16 teams, there are four national teams higher than Montenegro players, such as Turkey $(201 \mathrm{~cm})$, Slovenia $(200 \mathrm{~cm})$, France $(200$ $\mathrm{cm})$, and Russia $(200 \mathrm{~cm})$. It is important to note that these teams rank top six places. Montenegro, with an average height of 198, is equal in value to the first-ranked Spain, followed by Greece, Great Britain and Netherlands. Other teams have less value. On the other hand, the North Macedonian team competed in Division B, and it can be seen that the selections in that division are, on average, not as tall as the teams in Division A. All this is in support of the claim that success in basketball requires more values of individual longitudinal measures, such as body height (Ljubojevic \& Nikolic).

As we can see in Table IV, the North Macedonian team has lower height values in comparison with majority of the national teams at the Championship. For example, players of North Macedonia are lower in height than three first-ranked teams: Israel $(196 \mathrm{~cm})$, Poland $(197 \mathrm{~cm})$ and Czech Republic $(195 \mathrm{~cm})$, as well as the rest of lower placed national teams.

If we compare the results of body height, which are on the official FIBA website, with the results obtained in our study, we can see that the values differ. It is important to emphasize that this difference is due to the fact that height presented at FIBA website is a result of measurements of basketball players in their footwear. Therefore, in the further analysis we will compare the results obtained in our study.

The results of anthropometric measures showed that the average height of the both teams was lower than the values given by Vaquera et al. (2015) regarding Spanish national team U18 $(198.92 \pm 92 \mathrm{~cm})$ and the values from players from Greece $(198 \pm 8.14 \mathrm{~cm})$ by Gerodimos et al. (2005). In addition, the average height of Montenegrin players, as well as North Macedonian, shows higher results than resulted obtained by Efremovska et al. (2014), where the players from North Macedonia had values $(184.4 \mathrm{~cm})$. This shows us that players of North Macedonia back than also had lower results in average height. Also, similar results 
Table IV. Body height of national teams participating in FIBA U18 European Championship Division A, and Division B, from 2019 (http://www.fiba.basketball).

\begin{tabular}{clcccc}
\hline $\begin{array}{c}\text { Final } \\
\text { standings }\end{array}$ & DIVISION A & $\begin{array}{c}\text { Average } \\
\text { height }(\mathrm{cm})\end{array}$ & $\begin{array}{c}\text { Final } \\
\text { standings }\end{array}$ & $\begin{array}{c}\text { DIVISION B } \\
\text { Avrael }\end{array}$ & $\begin{array}{c}\text { Average height } \\
(\mathrm{cm})\end{array}$ \\
\hline 1. & Spain & 198 & 1. & Poland & 196 \\
2. & Turkey & 201 & 2. & Czech Republic & 197 \\
3. & Slovenia & 200 & 3. & North Macedonia & 195 \\
4. & Greece & 198 & $\mathbf{4 .}$ & Estonia & 199 \\
5. & France & 200 & 5. & Portugal & 191 \\
6. & Russia & 200 & 6. & Sweden & 194 \\
7. & Lithuania & 197 & 7. & Georgia & 198 \\
8. & Gr. Bretain & 198 & 8. & Ukraine & 192 \\
9. & Italy & 196 & 9. & Belgium & 196 \\
10. & Serbia & 197 & 10. & Iceland & 195 \\
11. & Germany & 197 & 11. & BIH & 194 \\
12. & Montenegro & $\mathbf{1 9 8}$ & 12. & Belarus & 195 \\
13. & Croatia & 196 & 13. & Bulgaria & 197 \\
14. & Finland & 195 & 14. & Hungary & 196 \\
15. & Netherlands & 198 & 15. & Ireland & 191 \\
16. & Latvia & 197 & 16. & & \\
\hline
\end{tabular}

appear in the analysis of the Tunisian National Team (Adbelkrim et al., 2010), whose average height is $192 \pm 7.6 \mathrm{c}$ $\mathrm{m}$. It is also worth comparing the results with the values of the 132 best European basketball players measured at the European Junior Championship in Croatia 2000 (Jelicic' et al., 2002). The average height was $195.44 \mathrm{~cm}$.

There for we can conclude that the average height of Montenegrin basketball players is on the average level, relative to the values of national selections. In favor of this reasoning, that high positioning in body height is supported by the fact that the population from which selection is made is very high, also noted by Popovic (2018), who claims that male Montenegrins, with an average height of 183.74 centimeters are very close to the tallest nation in the world, after Dutch $(183.8 \mathrm{~cm})$.

The average body weight values of Montenegro are higher than those of North Macedonia. This is expected given the difference in value in body height. The results of both selections are lower compared to Spanish players $(94.05 \mathrm{~kg})$, according to Vaquera et al., as well as the results of Greek players where the average value is $94.31 \mathrm{~kg}$ (Gerodimos et $a l$.). The results of weight of Montenegrin players are narrow to findings of Jelicic' et al., where the values of elite European basketball players is shown. Values of weight determined for Montenegrin players are greater than those for Tunisian players $(83.7 \mathrm{~kg}$ ), by Adbelkrim et al. This also applies to Macedonian players $(75.2 \mathrm{~kg}$ ) from the study by Efremovska et al. We can see here that higher scores in height and weight have selections that play at a higher level of competition and achieve better results.
Analyzing the results of the skinfolds, it was found that in most cases the players' values are consistent. The ttest showed statistical significance only in thigh skinfold (0.03). In addition, values of upper skinfolds (back skinfold, abdominal skinfold) are in favor of Montenegro, but that did not show special significance. Having this mind, it can be concluded that players have similar results.

If we compare the results obtained with the results available from other selections, we can conclude that the values of the skinfolds of triceps skinfold, abdomen skinfold, calf skinfold and thigh skinfold are lower than the results of Vaquera et al. (triceps- 11.4; back skinfold - 9.2; biceps skinfold 5.4; abdomen skinfold 14.6; calf skinfold 8.4; thigh skinfold 11.8), while the results of back skinfold and biceps skinfold have approximate values.

Compared to the results of Jelicic' et al. triceps skinfold (9.3), back skinfold (9.1), biceps skinfold (4.2), abdomen skinfold (11.3), calf skinfold (8.2) and thigh skinfold (13.6), we can conclude that the results of Montengro and North Macedonia are lower for triceps skinfold, calf skinfold and thigh skinfold, while the values are higher for back skinfold and abdomen skinfold and the approximate values are found for biceps skinfold.

Observing the results of values of BMI for Montenegro and North Macedonia we can conclude that there are no significant differences between the two national teams. We can say that these results are the same in comparison with other studies: Spain $(23.97 \pm 1.09)$ by Vaquera et al., Greece (24.02 \pm 1.49$)$ by Gerodimos et al., North 
Macedonia (22.03 \pm 2.01$)$ by Efremovska et al., Tunis (22.7 \pm 0.8$)$ by Adbelkrim et al., as well as results by Jelicic' et al. for European Championship (23.24). This can be explained by the fact that players are of the same age, characterized by accelerated growth and development of the organism.

In order to have excellent motoric movements mentioned above we must emphasize that the value of body fat component is important from physiological point of view. Statistical significance wasn't obtained for the fat percentage variable. The results of average value of those national teams are better, compared to the value from Kosovo, according to Kryeziu et al. (2018), where the values are $14.48 \pm 1.05$, and in the case of North Macedonia (Efremovska et al.), where the values are $15.24 \pm 1$.64. Also, slightly higher results (12.6 \pm 3.0$)$ were obtained by Adbelkrim et al. for Tunisian players and Jelicic' et al., who received an average value of $13.23 \%$ of Junior European Championship participants. More results (14.64) are also found with Mexico players (Ochoa), while there are similar results of the highest level basketball players from Greece, according to Gerodimos et $a l$., whose fat percentage was $11.12 \pm 2.35$. It should be noted that Montenegrin and North Macedonian players have good results when it comes to fat percentage, which can affect their motor performance, as it is known that players with lower body fat content would invariably perform at a higher level than those with higher body fat (Ostojic et al., 2006). Perhaps the reason for these results lies in the diversity of the traditional national diet of this region. This cannot be justified, as the nutrition of athletes is designed based on their daily needs (Ljubojevic et al.).

Results of the muscle mass value were in favor of Montenegro while North Macedonia national team measured some lower results, but this did not show notable significance. However, compared to the results obtained by Efremovska et al, that showed 37.14 \pm 5.86 , we may conclude that both national teams show higher values.

\section{CONCLUSION}

The subject of this paper was to study the morphological status of top elite youth male basketball players, who are members of two national selections that participated in the 2019 European Championship. The goal was also to obtain quantitative data that can be used to determine the morphological model and define control of the morphological status of elite young basketball players.

The results showed that Montenegro players are ta- ller than the players of North Macedonia and their average height is slightly lower than the best European teams, but it is also greater than most European Championship participants, as well as other compared selections. The players of North Macedonia have the lowest values in comparison to the teams participating in the European Championship and in comparison with the other teams. The body weight values of these two teams are slightly lower than Spain and Greece selections, higher than Tunisia and North Macedonia selections, but they are at the same level with the values of players of the 2000 European Championship.

It was also found that Montenegrin and North Macedonian players had similar values of skinfolds, as well as BMI values. Skinfolds of those two national teams had better results in comparison to other selections. Also, compared to Kosovo, Macedonia, Tunisia and Mexico, Montenegro and North Macedonia they have lower percentage fat value and are roughly similar to Greece.

Finally, we can conclude that results obtained in this research can serve to compare future national selections of Montenegro and North Macedonia. But, also, to be used in comparison with other selections that achieve better results than those treated here.

\section{ACKNOWLEDGEMENTS}

We thank the players and the staff of the two national teams for their cooperation during this search and survey.

LJUBOJEVIC, M.; BOJANIC, D.; KRIVOKAPIC, D.; NOKIC, A. \& DUKANOVIC, N. Diferencias en las características antropométricas y la composición corporal entre dos equipos nacionales de baloncesto masculino juvenil de élite - Participantes en el Campeonato de Europa U18 2019. Int. J. Morphol., 38(6):1528-1534, 2020.

RESUMEN: El objetivo de esta investigación fue determinar las diferencias en las características antropométricas y composición corporal entre los jugadores de baloncesto masculino del equipo nacional de Montenegro U18 y el equipo nacional de la República de Macedonia del Norte. Una muestra de 27 sujetos se dividió en dos submuestras. La primera sub muestra consistió en 15 jugadores del equipo nacional de Montenegro, con una edad promedio de 17,6 \pm 0,63 años. La otra muestra consistió en 12 jugadores del equipo nacional de la República de Macedonia del Norte, con un promedio edad de 17,17 $\pm 0,72$ años. Todos los jugadores fueron evaluados en Podgorica, durante un período de dos días, mientras realizaban los preparativos para el Campeonato de Europa. Las características antropométricas y la composición cor- 
poral se evaluaron mediante una batería de once variables: altura (cm), peso (kg), pliegue de tríceps, pliegue de espalda, pliegue de bíceps, pliegue abdominal, pliegue de muslos, pliegue de pantorrilla, índice de masa corporal (IMC), porcentaje de grasa y masa muscular $(\mathrm{kg})$. Se determinaron las diferencias en las características antropométricas y la composición del cuerpo de los jugadores de baloncesto de dos equipos nacionales a traves de un procedimiento paramétrico discriminatorio con prueba $t$ para muestras independientes $(\mathrm{p}<0,05)$. Se determinó que los jugadores de ambos equipos difieren estadísticamente en el pliegue del muslo. Además, se concluyó que en comparación con los jugadores de Macedonia del Norte los jugadores de Montenegro son de mayor altura y peso, además de contar con una mayor masa muscular, con valores aproximados de pliegues cutáneos, IMC y porcentaje de grasa.

PALABRAS CLAVE: Características antropométricas; Composición corporal; Jóvenes jugadores de baloncesto.

\section{REFERENCES}

Adbelkrim, N. D.; Chaouachi, A.; Chamari, K.; Chtara, M. \& Castagna, C. Positional role and competitive-level differences in elite-level men's basketball players. J. Strength Cond. Res., 24(5):1346-55, 2010.

Carter, J. E. L.; Ackland, T. R.; Kerr, D. A. \& Stapff, A. B. Somatotype and size of elite females basketball players. J. Sports Sci., 23(10):1057-63, 2005.

Claessens, A. L.; Veer, F. M.; Stijnen, V.; Lefevre, J.; Maes, H.; Steens, G. \& Beunen, G. Anthropometric characteristics of outstanding male and female gymnasts. J. Sports Sci., 9(1):53-74, 1991.

Efremovska, L.; Nikolic, S.; Maleska-Ivanovska, V.; PluncevicGligorovska, J.; Todorovska, L.; Karagjozova, I. \& Ivanovska, E. Analysis of Body Mass Components in Young Basketball Players. Lugano, 5th International Conference on 3D Body Scanning Technologies, 2014.

Gerodimos, V.; Manou, V.; Kellis, E. \& Kellis, S. Body composition characteristics of elite male basketball players. J. Hum. Mov. Stud., (49):115-26, 2005.

Jelicic, M.; Sekulic, D. \& Marinovic, M. Anthropometric characteristics of high level European junior basketball players. Coll. Antropol., 26 Suppl.:69-76, 2002.

Kryeziu, A.; Begu, B. \& Asllani, I. Structure of morphological characteristics of young basketball players. Sport Sci., 11(1):61-3, 2018.

Ljubojevic, M. \& Nikolic, B. Antropometrijske karakteristike i motoricke sposobnosti mladih kosarkasa Crne Gore. Sport Mont., 34-35-36:17480, 2012.

Ljubojevic, M.; Bojanic, D.; Bjelica, D.; Vasiljevic, I. \& Vukotic, M. Differences in Anthropometric characteristics between two elite female basketball national teams - participants at Eurobasket 2019 in Latvia and Serbia. Int. J. Morphol., 38(4):857-62, 2020.

Masanovic, B. Comparative study of morphological characteristics and body composition between different team players from Serbian Junior National League: soccer, handball, basketball and volleyball. Int. J. Morphol., 37(2):612-9, 2019.

Ochoa, M. P. Y.; Hall, L. J. A.; Alarcón, M. E. I., Arráyales, M. E. M. \& Sánchez, L. R. (2014). Somatotype profile and body composition of players from the Mexican professional basketball league. Int. J. Morphol., 32(3):1032-5, 2014.

Ostojic, S. M.; Mazic, S. \& Dikic, N. Profiling in basketball: physical and physiological characteristics of elite players. J. Strength Cond. Res., 20(4):740-4, 2006.
Popovic, S. Arm-span measurement as an alternative estimation of true height in Montenegrin young adults of both sexes: A national survey. Anthropol. Note., 24:53-67, 2018.

Popovic, S.; Akpinar, S.; Jaksic, D.; Matic, R. \& Bjelica, D. Comparative study of anthropometric measurement and body composition between elite soccer and basketball players. Int. J. Morphol., 31(2):461-7, 2013.

Riezebos, M. L.; Paterson, D. H.; Hall, C., R. \& Yuhasz, M. S. Relationship of selected variables to performance in women's basketball. Can. J. Appl. Sport Sci., 8(1):34-40, 1983.

Shambaugh, J. P.; Klein, A. \& Herbert, J. H. Structural measures as a predictors of injury in basketball players. Med. Sci. Sports Exerc., 23(5):522-7, 1991.

Sisodiya, A. \& Yadaf, M. Relationship of anthropometric variables to basketball playing ability. J. Adv. Dev. Res., 1(2):191-4, 2010.

Vaquera, A.; Santos, S.; Villa, J. G.; Morante, J. C. \& García-Tormo, V. Anthropometric characteristics of Spanish professional basketball players. J. Hum. Kinet., 46:99-106, 2015.

Corresponding author:

Milovan Ljubojevic, PhD, Assistant Professor

Faculty for Sport and Physical Education

University of Montenegro

81400, Niksic

MONTENEGRO

Email: milovan.lj@ucg.ac.me

Received: $13-04-2020$

Accepted: 14-06-2020 